\title{
Impact of the Good University Governance Implementation to Measure Stakeholder Satisfaction STIE Rajawali Purworejo
}

\author{
Nur Siyami, SE., M.Ak \\ Accounting Major \\ STIE Rajawali Purworejo \\ Purworejo \\ Mharsya.imut@gmail.com
}

\begin{abstract}
In the midst of tough competition, quality improvement is inevitable in order to compete for public trust and continue to exist. Higher education institutions are required to be able to provide the best possible service to the community and be oriented towards the needs of the community. Academic services and their supporting facilities are one of the considerations for prospective students in choosing universities to continue their education. So that service quality is one indicator of the success of educational institutions as a public organization. Because of the existing background and considering the urgency of the Good University Governance factor, researchers are interested in measuring "The Impact of the Implementation of Good University Governance to Measure Stakeholder Satisfaction of Stie Rajawalipurworejo". Data collection techniques in this study were obtained by means of observation, interviews, questionnaires, documentation and literature study. The sampling technique used was acedental sampling, namely the determination of the sample based on chance while the number of samples in the study was 75 people from the
\end{abstract}

Keywords: Good University Governance, Stakeholder Satisfaction

\section{INTRODUCTION}

Higher Education is an institution that is closely related to increasing economic growth and the role of society. In this case the capacity of universities is not only as creators and disseminators of knowledge, but higher education is an institution that is able to accommodate potential resources, generate new ideas, enrich the quality of life and culture as well as agents of change (Muktiyanto 2016).

In this case, STIE Rajawali tries to take a role by organizing an entrepreneurship-based lecture process where students are given course material according to current and future conditions and needs. In addition, lecturers also provide practicum activities that are formulated based on real matters and activities that support student competence. In line with the vision and mission of STIE Rajawali in order to create graduates who are able to compete in the global economy.

The real role of STIE Rajawali in the field of education is to create competent graduates in both accounting and management based entrepreneurship. In this case, STIE Rajawali tries to align the vision and mission of the institution, the educational curriculum and stakeholder expectations of the quality and qualifications of STIE RajawaliPurworejo graduates. One of the efforts made by the
Accounting Study Program is to reform the curriculum in order to create graduates with entrepreneurial-based accounting competencies. The curriculum is stated in courses, both theory, practicum and student assistance directly in activities in the field that support the achievement of goals, visions, missions. In addition, the Study Program at STIE Rajawali Purworejo formulates an entrepreneurshipbased curriculum development program in collaboration with various parties including MSMEs, related agencies, local governments, Alumni Users and other stakeholders.

In realizing its vision and mission STIE Rajawali Purworejo applies the principles of Good University Governance which prioritizes the 5 pillars of GUG which includes several measurement aspects. All this shows the need for the importance of efficient and effective governance arrangements, in order to achieve the vision and mission and strategy. In the context of higher education in Indonesia, these challenges and trends have been caught and addressed by the Ministry of National Education, Directorate General of Higher Education, which has launched the Higher Education Long Term Strategy (HELTS) concept for 20032010 which rests on three main pillars, namely : autonomy, organizational health, and nation's competitiveness. The three pillars can be realized properly if the concept of Good University Governance (GUG) is implemented seriously. Rizal Z Tamim stated that higher education autonomy can be realized if universities carry out GUG well. The same thing, Djanali (2005) states that to be able to improve the quality of university elements must be supported by a good governance system method. Meanwhile, according to Wijatno (2009) there were five GUG principles, namely, (1) transparency, (2) accountability, (3) responsibility, (4) independence, and (5) justice. Meanwhile, BPKP and LAN (2000) require that there are several things that need to be considered in the implementation of GUG in Indonesia, namely (1) transparency or openness; (2) accountability; (3) responsiveness; and (4) equality of degree and inclusivity. STIE Rajawali from year to year has not experienced a significant development. Private tertiary institutions (PTS) in this case are required to be able to maintain their existence to compete to attract the public's interest in choosing their institution. However, the competition for PTS in fighting for the student market is quite tough considering that there are so many universities in Indonesia that reach 3,151 universities (PT). Of the many universities, 3,068 or $97 \%$ were private universities, while PTN only amounted to 83 or $3 \%$ (APTISI, 
In the midst of tough competition, quality improvement is inevitable in order to compete and gain public trust and continue to exist. Higher education institutions are required to be able to provide the best possible service to the community and be oriented to the needs of the community. Academic services and their supporting facilities are one of the considerations for prospective students in choosing a university to continue their education. So that the quality of service is one indicator of the success of an educational institution as a public organizations. Because of the existing background and considering the urgency of the Good University Governance factor, researchers are interested in measuring "THE IMPACT OF THE IMPLEMENTATION OF GOOD UNIVERSITY GOVERNANCE TO MEASURE STAKEHOLDER SATISFACTION STIE RAJAWALIPURWOREJO".

\section{LITERATURE REVIEW}

\section{A. Agency Theory}

Jensen and Mackling (1976) are the pioneers of agency theory, which explains that there are differences in interests between principals (in this case company owners) and agents (in this case company managers). The agent as the manager of the company knows more about the information inside the company, while the principal has less information in the company.

\section{B. $\quad$ Stewardship Theory}

Puspitarini (2012) states that management is a party that can be trusted to act as well as possible for the public interest in general and shareholders in particular. In line with the agency approach, stewardship theory suggests that corporate governance of an organization is necessary to ensure stakeholder interests and the long-term survival of the organization (Davis, Schoorman \& Donaldson 1997).

\section{Good University Governance (GUG)}

Shattock (2006) explains that university governance is a constitutional form and process when a university manages its own affairs. Meanwhile, governance itself will involve the existence of a policy and procedure in terms of decisionmaking and control actions to provide direction in effective organizational management (Carnagie 2009). The following is an explanation of each principle as follows:

\section{Transparency (Transparency)}

Transparency means that decision making and implementation are carried out in a manner that follows laws and regulations. Transparency also means that information is freely available and directly accessible to those who will be affected by the decision.

\section{Responsibility}

Responsibility, namely the extent to which policies, regulations, and budget allocations receive support and positive responses from the academic community. response of public servants that can fulfill the wishes of stakeholders.

Equality and fairness

Fairness is a governance principle that prioritizes protection for minority stakeholders in terms of gender, economy, geography and others, is protected from fraud, self-dealing or misconduct.

\section{Stakeholder Satisfaction}

The ability of a company to be able to recognize, fulfill and satisfy customer needs properly is a strategy for every company. Customer satisfaction has become a central concept in business discourse.

\section{E. Hypothesis Development}

Machmuddah research (2019) proves that GUG has an effect on student satisfaction. In addition, it is also in line with the research of Wahyudin, et al. (2017), Muktiyanto (2016), Amilin (2016), Muhi (2010) and Brown (2001) have proven that GUG affects higher education performance. This argument is used as a basis for building a hypothesis, therefore the hypothesis in this study is as follows:

H1: Transparency has a significant effect on stakeholder satisfaction College.

$\mathrm{H} 2$ : Accountability has a significant effect on university stakeholder satisfaction.

H3 : Responsibility has a significant effect on the satisfaction of university stakeholders.

H4 : Independency has a significant effect on university stakeholder satisfaction.

H5 : Fairness has a significant effect on university stakeholder satisfaction.

\section{RESEARCH METHODS}

All Stakeholders of STIE Rajawali Purworejo were the population in this study. The samples used in this study were part of the lecturers, students, graduates and stakeholders of higher education institutions in Purworejo Regency, because the sampling technique was carried out by accidental sampling. This research method by conducting a survey. The data were obtained by distributing questionnaires to selected respondents. The research.

Variable is that the researcher chooses the object to be studied and then draws the conclusion (Sugiyono 2011). This section contains a description of the variables studied, it must be defined more operationally. After being defined the research variables must be measured according to the rules, and generally accepted academically. This study uses two variables, namely the independent variable and the dependent variable

\section{DATA ANALYSIS TECHNIQUE}

\section{A. Validity Test}

Validity is a measure that shows the levels of validity of a variable (Arikunto, 1998: 160). A variable is said to be valid if it can reveal data from the variable under study appropriately. The level of variable validity indicates the extent to which the data collected and deviates from the description of the intended variables. Based on the validity test, it can be seen that of the 10 question items, all question items are declared valid and can be forwarded to the next test. All question items were declared valid because they had a validity value of $\geqslant 0.3$. 


\section{B. Reliability Test}

Reliability test is used to show to what extent an instrument provides consistent measurement results, if measurements are repeated (Azwar, 2002: 45). For the reliability test with the Alpha Chronbach method if Alpha $\geqslant 0.6$ means that the measuring instrument is reliable and the questionnaire meets the reliability requirements. Based on the reliability test, it can be seen that of the 10 question items, all question items are declared valid and can be forwarded to the next test. All question items were declared valid because they had a reliability value of $\geqslant 0.6$.

\section{Simple Regression Test}

Simple linear regression is used to determine the effect of the impact of the implementation of Good University Governance on STIE Rajawali Stakeholder Satisfaction through a simple linear regression equation. Based on the results of the spss version 23 output shown by the table shown in table 4 , the simple linear regression line equation can be stated as follows $\mathrm{Y}=38,213+0.200 \mathrm{X}$. The value of the constant coefficient is 38,213 . This means that if the value of the variable good university governance is 0 (zero), then the level or magnitude of the stakeholder satisfaction variable is 38,213 . The variable good university governance has a coefficient of 0.200 . The value of 0.200 means that if the value of the variable good university governance increases by 1 unit and the other variables are considered constant, the level of stakeholder satisfaction is 0.200 .

TABLE 1

SIMPLE REGRESSION TEST

\begin{tabular}{|c|c|c|c|c|c|}
\hline \multirow[b]{2}{*}{ Model } & \multicolumn{2}{|c|}{$\begin{array}{c}\text { Unstandardiz } \\
\text { ed } \\
\text { Coefficients }\end{array}$} & \multirow{2}{*}{$\begin{array}{c}\begin{array}{c}\text { Standardi } \\
\text { zed } \\
\text { Coefficien } \\
\text { ts }\end{array} \\
\text { Beta }\end{array}$} & \multirow[b]{2}{*}{$\mathrm{t}$} & \multirow[b]{2}{*}{ Sig. } \\
\hline & B & $\begin{array}{l}\text { Std. } \\
\text { Error }\end{array}$ & & & \\
\hline $\begin{array}{l}1 \text { (Consta } \\
\text { nt) }\end{array}$ & 38.213 & $\begin{array}{r}4.25 \\
1\end{array}$ & & 8.989 & .000 \\
\hline GUG & .200 & .132 & .213 & 1.508 & .038 \\
\hline
\end{tabular}

a. Dependent Variable: KEPUASAN

STAKEHOLDER

Fig. 1 Simple Regression Test

D. t test

The $t$ statistical test is used to measure how much influence the independent variables individually have in explaining the variation in the dependent variable. If the t-count value is greater than the t-table value, it can be stated that the independent variable individually has a positive effect on the dependent variable. If the significance value of $t \leqslant 0.05$, it can be stated that the independent variables individually have a significant effect on the dependent variable.
TABLE 2 T TEST

\begin{tabular}{|c|c|c|c|c|c|}
\hline \multirow[b]{2}{*}{ Model } & \multicolumn{2}{|c|}{$\begin{array}{c}\text { Unstandardiz } \\
\text { ed } \\
\text { Coefficients }\end{array}$} & \multirow{2}{*}{$\begin{array}{c}\text { Standardi } \\
\text { zed } \\
\text { Coefficien } \\
\text { ts } \\
\text { Beta } \\
\end{array}$} & \multirow[b]{2}{*}{$\mathrm{t}$} & \multirow[b]{2}{*}{ Sig. } \\
\hline & B & $\begin{array}{l}\text { Std. } \\
\text { Error }\end{array}$ & & & \\
\hline $\begin{array}{ll}1 & \text { (Consta } \\
\text { nt) }\end{array}$ & 38.213 & $\begin{array}{r}4.25 \\
1\end{array}$ & & 8.989 & .000 \\
\hline GUG & .200 & .132 & .213 & 1.508 & .038 \\
\hline
\end{tabular}

a. Dependent Variable: KEPUASAN STAKEHOLDER

Fig. $2 \mathrm{t}$ test table

\section{E. The coefficient of determination}

The coefficient of determination (R2) is used to determine the high degree of the independent variables together on the dependent variable. To find the coefficient of determination in general, squaring the regression coefficient. Based on table 6 , it is known that the value value on the Adjusted $R$ Square is 0.64 , this number is called the coefficient of determination. The value of determination is 0.64 or $64 \%$. This figure means that $64 \%$ of the level of stakeholder satisfaction can be explained by using the Good University Governance variable which includes transparency, accountability, responsibility, independence and fairness. While the remaining 36\% (100\% -64\%) may be influenced by other variables that are not examined in the indicators of Good University Governance.

TABLE 3

THE COEFFICIENT OF DETERMINATION

\begin{tabular}{|l|c|r|r|r|}
\hline $\begin{array}{l}\text { Mode } \\
1\end{array}$ & \multicolumn{1}{|c|}{$\mathrm{R}$} & $\mathrm{R}$ Square & $\begin{array}{c}\text { Adjusted R } \\
\text { Square }\end{array}$ & $\begin{array}{l}\text { Std. Error of } \\
\text { the Estimate }\end{array}$ \\
\hline 1 & $.213^{\mathrm{a}}$ & .85 & .64 & 2.30615 \\
\hline
\end{tabular}

a. Predictors: (Constant), GUG

Fig. 3 Coeffcient of Determination

\section{F. Research Results on the Effect of GUG on Stakeholder Satisfaction}

The simple linear regression analysis test results presented in table 5 show that the level of significance of the variable good university governance on stakeholder satisfaction is 0.038 , this means that the variable good university governance has a positive effect on the satisfaction of university stakeholders. Principles of Openness, Accountability, Responsibility, Independence, and Justice carried out by universities through study programs that are represented by easy access to accurate, relevant and easy to understand information so that it becomes an indicator of satisfaction for interested parties. This is in accordance with the agency approach and stewardship theory which explains that corporate governance of an organization is needed to ensure stakeholder interests and the long-term survival of the organization (Davis, Schoorman \& Donaldson, 1997). Management behavior will not deviate from organizational interests because management seeks to optimize organizational goals where management utility is maximized because organizational success is very important to achieve management's mission (Smallman 2004). The findings of this study are in line with the findings of 
research conducted by Machmuddah (2019), Wahyudin, et al. (2017), Muktiyanto (2016), Amilin (2016), Nofianti and Suseno (2014), Gupta and Sharma (2014), Muhi (2010) and Brown (2001). However, the findings of this study are not in line with the research of Leni and Rasyd (2010) and Anggriawan and Nurkholis (2014).

\section{CONCLUSION, LIMITATIONS AND SUGGESTIONS}

The results of the study prove that the variables of Good University Governance which are formulated with transparency, responsibility, fairness, accountability and independence have a significant effect on stakeholder satisfaction of STIE Rajawali Purworejo. The implication of this research is to prove that good university governance plays a role in stakeholder satisfaction, so that universities are required to implement good university governance to improve university performance and stakeholder satisfaction. The limitation of this study is the limitations of respondent feedback so that the data in this study is very minimal. The suggestion of this research is to increase the amount of research data so that the results can generalize to higher education institutions in Indonesia.

\section{REFERENCES}

[1] A. Amilin, "Measuring the correlation of job satisfaction with accountants performance: The role of Islamic work ethics as a moderator," Eur. Res. Stud. J., 2016, doi: 10.35808/ersj/590.

[2] K. H. Chung and H. Zhang, "Corporate governance and institutional ownership," J. Financ. Quant. Anal., 2011, doi: 10.1017/S0022109010000682.

[3] M. C. Jensen and W. H. Meckling, "Theory of the firm: Managerial behavior, agency costs and ownership structure," $J$. financ. econ., 1976, doi: 10.1016/0304-405X(76)90026-X.

[4] "Managing Good Governance in Higher Education," Perspect. Policy Pract. High. Educ., 2008, doi: 10.1080/13603100802002644.

[5] M. Shattock, Managing Universities and Colleges: Guides to good practice Managing Universities and Colleges: Guides to good practice in Higher. 2006.

[6] "INTERNAL CONTROLS IN ENSURING GOOD CORPORATE GOVERNANCE IN FINANCIAL INSTITUTIONS," Ann. Univ. Petrosani - Econ., 2011.

[7] K. Kelley, B. Clark, V. Brown, and J. Sitzia, "Good practice in the conduct and reporting of survey research," International Journal for Quality in Health Care, vol. 15, no. 3. pp. 261-266, 2003, doi: 10.1093/intqhc/mzg031. 